\title{
Pengembangan Bahan Ajar Modul dengan Pendekatan Discovery Learning pada Materi Himpunan
}

\author{
Nanik Saputri ${ }^{1 *}$, Isnaini Nur Azizah ${ }^{2}$, Hernisawati $^{3}$
}

\author{
1,2 Jurusan Pendidikan Matematika, Fakultas Tarbiyah, Institut Agama Islam NU Metro, \\ Jl. RA Kartini. 28 Purwosari Metro Utara Kota Metro 34118, Indonesia
}

${ }^{3}$ Jurusan Bimbingan Konseling Pendidikan Islam, Fakultas Tarbiyah, Institut Agama Islam NU Metro, Jl. RA Kartini. 28 Purwosari Metro Utara Kota Metro 34118, Indonesia

\begin{tabular}{|c|c|}
\hline INFO ARTIKEL & ABSTRAK \\
\hline $\begin{array}{l}\text { * Penulis Korespondensi. } \\
\text { Email: } \\
\text { naniksaputri1998@gmail.com }\end{array}$ & $\begin{array}{l}\text { Penelitian ini secara umum bertujuan untuk menghasilkan produk } \\
\text { bahan ajar Modul dengan pendekatan Discovery Learning pada } \\
\text { materi himpunan, dan tujuan khususnya untuk mengetahui } \\
\text { bagaimana pengembangan dan kemenarikan bahan ajar Modul } \\
\text { dengan pendekatan tersebut. Penelitian ini menggunakan metode } \\
\text { pengembangan model Thiagarajan } 4 \mathrm{D} \text {, yang terdiri dari } 4 \text { tahapan, } \\
\text { yaitu definisi, desain, pengembangan, dan penyebaran. Hasil } \\
\text { penelitian pengembangan bahan ajar Modul dengan pendekatan }\end{array}$ \\
\hline $\begin{array}{l}\text { Disetujui: } \\
3 \text { Mei } 2020 \\
\text { Online } \\
3 \text { September } 2020\end{array}$ & $\begin{array}{l}\text { Discovery Learning. : (1) Hasil utama dari penelitian dan } \\
\text { pengembangan ini adalah bahan ajar Modul dengan pendekatan } \\
\text { Discovery Learning. (2) Data penelitian menunjukan bahwa ahli } \\
\text { materi diperoleh nilai rata-rata sebesar } 76 \% \text { dengan kriteria "layak", } \\
\text { ahli desain diperoleh nilai rata-rata sebesar } 78 \% \text { dengan kriteria } \\
\text { "layak", dan ahli bahasa diperoleh nilai rata-rata sebesar } 79 \% \text { dengan }\end{array}$ \\
\hline $\begin{array}{l}\text { Format Sitasi: } \\
\text { N. Saputri, I.N. Azizah and } \\
\text { H. Hernisawati, } \\
\text { "Pengembangan Bahan Ajar } \\
\text { Modul dengan Pendekatan } \\
\text { Discovery Learning pada } \\
\text { Materi Himpunan," Jambura } \\
\text { J. Math. Educ., vol. 1, no. 2, } \\
\text { pp.48-58, 2020. }\end{array}$ & $\begin{array}{l}\text { kriteria "layak". (3) Untuk respon pengguna terhadap bahan ajar } \\
\text { modul dengan pendekatan discovery learning dari respon peserta } \\
\text { didik memperoleh nilai rata-rata } 74 \% \text { dengan kriteria yaitu } \\
\text { "menarik" dan respon dari pendidik memperoleh persentase } 74 \% \\
\text { dengan kriteria interpretasi yang dicapai yaitu "menarik". } \\
\text { Signifikansi dari penelitian ini antara lain, yaitu peneliti dapat } \\
\text { mengembangkan sebuah bahan ajar dalam bentuk modul } \\
\text { pembelajaran yang dapat meningkatkan keaktifan dan keefektifan } \\
\text { peserta didik dalam menjalankan proses belajar mengajar di kelas. }\end{array}$ \\
\hline $\begin{array}{l}\text { Lisensi: } \\
\text { JMathEdu is licensed under }\end{array}$ & Kata Kunci: Modul; Discovery Learning; Himpunan \\
\hline$\underline{\text { Attribution-NonCommercial }}$ & $\begin{array}{l}\text { This research generally aims to produce Module teaching material products } \\
\text { with the Discovery Learning approach to the set material, and the specific } \\
\text { purpose is to find out how the development and attractiveness of the Module }\end{array}$ \\
\hline $\begin{array}{l}\text { Copyright (C) } 2020 \text { Jambura } \\
\text { Journal of Mathematics } \\
\text { Education }\end{array}$ & $\begin{array}{l}\text { teaching materials with that approach. This study uses the Thiagarajan } 4 D \\
\text { model development method, which consists of } 4 \text { stages, namely definition, } \\
\text { design, development, and dissemination. The results of the research on the } \\
\text { development of the Modules teaching material with the Discovery Learning } \\
\text { approach.: (1) The main results of this research and development are Module } \\
\text { teaching materials with the Discovery Learning approach. (2) Research data } \\
\text { shows that material experts obtained an average value of } 76 \% \text { with the } \\
\text { criteria of "feasible", design experts obtained an average value of } 78 \% \text { with } \\
\text { the criteria of "feasible", and linguists obtained an average value of } 79 \% \\
\text { with the criteria "feasible". (3) For the user's response to the teaching } \\
\text { materials of the module with the discovery learning approach of the response } \\
\text { of students obtained an average value of } 74 \% \text { with the criteria that is } \\
\text { "interesting" and the response from educators gained a percentage of } 74 \% \\
\text { with the interpretation criteria achieved namely "interesting". The }\end{array}$ \\
\hline
\end{tabular}


significance of this research, among others, is that researchers can develop teaching material in the form of learning modules that can increase the activeness and effectiveness of students in carrying out teaching and learning in the classroom.

Keywords: Module; Discovery Learning; Set

\section{Pendahuluan}

Berdasarkan hasil prasurvey yang penulis lakukan di MTs. Darul A'mal Metro dapat diketahui bahwa permasalahan yang terjadi di kelas VII adalah sebagian besar peserta didik mengantuk saat pembelajaran di kelas karena pembelajaran yang bersifat monoton sehingga siswa cepat merasa bosan. Selain itu penggunaan pendekatan diskusi sebagai pendekatan pembelajaran matematika pada kelas putri sudah berjalan dengan baik tetapi pada kelas putra belum bisa berjalan dengan baik. Sebagai bahan ajar utama yang digunakan adalah Lembar Kerja Siswa (LKS) sedangkan modul matematika masih dirancang [1]. Selain itu, peserta didik juga mengalami kesulitan dalam mempelajari materi himpunan. Salah satunya, peserta didik mengalami kesulitan dalam mengerjakan soal himpunan yang berbasis soal cerita.

Menyoroti masalah tersebut maka diperlukan sebuah bahan ajar yang sesuai dengan karakterirtik peserta didik. bahan ajar tersebut dipadupadankan dengan pendekatan pembelajaran yang tepat. Penggunaan bahan ajar memudahkan peserta didik dalam belajar dan memahami materi. Bahan ajar adalah semuan alat yang digunakan pendidik untuk melakukan pembelajaran di dalam kelas. Bahan ajar tersebut bisa dalam bentuk tertulis ataupun tidak tertulis. Salah satu bahan ajar yang dapat digunakan adalah bahan ajar Modul. Menurut Purwanto dkk, modul adalah bahan ajar yang dibuat sesuai dengan kurikulum yang telah ditetapkan di sekolah dan dirancang dalam perangkat pembelajaran guna memudahkan peserta didik dalam memahami materi serta membuat pembelajaran lebih efesien [2]. Hingga saat ini, pengembangan bahan ajar atau modul dalam pembelajaran matematika masih terus dilakukan, seperti yang dapat dilihat pada [3][4][5].

Selain menggunakan modul juga perlu didukung dengan pendekatan pembelajaran. Dalam penggunaan modul pendekatan pembelajaran ini harus tepat, menarik dan sesuai dengan karakter peserta didik serta mengaktifkan peserta didik dalam proses belajar mengajar. Salah satu pendekatan pembelajaran yang berorientasi pada hal tersebut adalah pendekatan pembelajaran Discovery Learning. Menurut Russefendi, Discovery Learning adalah pendekatan dalam mengajar yang menuntut peserta didik untuk kreatif dan aktif untuk mendapatkan pengetahuan yang belum diketahui sebelumnya tanpa diberitahu langsung oleh pendidik, mereka mencari sebagian ataupun seluruhnya sendiri [6].

Hal serupa dikemukakan oleh Bruner: "Discovery Learning can be defined as the learning that takes place when the student is not presented with subject matter in the final form, but rarther is required to organize it him self' [7] Maksudnya Discovery juga dapat diartikan bahwa materi pembelajaran tidak disediakan dalam bentuk yang sudah jadi, melainkan peserta didik dituntun untuk mengatur dan menyusun materi pembelajaran dengan sendirinya. Dalam literatur lain juga dijelaskan bahwa Discovery Learning (pembelajaran discovery) adalah cara atau teknik pembelajaran dimana seorang pendidik dituntut untuk lebih kreatif dalam menciptakan sebuah situasi yang dapat membuta peserta didik belajar lebih aktif untuk menemukan pengalaman dan pengetahuannya sendiri [8]. 
Dari beberapa pendapat diatas dapat disimpulkan bahwa Discovery Learning merupakan metode, cara ataupun teknik yang digunakan oleh pendidik dimana dalam metode ini peserta didik dituntun untuk menggali sebuah pengetahuan dan pengalaman dengan sendirinya tanpa disediakan secara utuh oleh pendidik. Peserta didik juga dituntut untuk lebih aktif dan kreatif.

Seperti yang diklarifikasi bahwa dalam matematika perlu pemahaman konsep yang sangat mendasar. Pendekatan discovery learning peserta dituntut untuk mencari, menemukan dan menjelaskan sendiri materi pembelajaran. Salah satu materi matematika yang bisa untuk digabungkan dengan pendekatan ini adalah materi himpunan. Karena didalam himpunan menjabarkan tentang objek-objek nyata yang ada di sekitar kita. Materi ini sangat cocok digabungkan dengan pendekatan discovery learning karena peserta didik bisa mencari dan menemukan mana yang disebut dengan himpunan dan mana yang bukan himpunan yang ada di lingkungan sekitarnya. Sehingga peserta didik bisa lebih mudah memahami dan mengerjakan contoh-contoh soal himpunan. Terlebih lagi peserta didik masih mengalami kesulitan dalam mengerjakan soal cerita. Sedangkan contoh-contoh soal dalam bahan ajar modul dengan pendekatan Discovery Learning ini mengambil objek-objek yang ada di lingkungan sekitar peserta didik. Jadi peserta didik lebih mudah dalam menyelesaikan soal-soal cerita pada materi himpunan.

\section{Metode}

Penelitian ini menggunakan jenis penelitian dan pengembangan (Research and Development). Research and Development merupakan suatu proses atau langkah-langkah untuk mengembangkan suatu produk baru atau menyempurnakan produk yang sudah ada yang dapat dipertanggungjawabkan [9]. Model pengembangan pada penelitian ini menggunakan metode pengembangan perangkat pembelajaran model 4D yang disarankan oleh S. Thiagharajan. 4 tahap pengembangan tersebut adalah Define, Design, Develop, Disseminate [10] kemudian dikembangkan menjadi metode 4P yaitu: pendefinisian, perencanaan, pengembangan, dan penyebaran [11]. Tetapi pada penelitian ini tahapan penyebaran (disseminate) tidak dilakukan karena mebutuhakn waktu yang lebih lama dan keterbatasan biaya yang dimiliki peneliti.

\subsection{Langkah-langkah pengembangan modul dengan pendekatan Discovery Learning}

\subsubsection{Tahap I: Pendefenisian (Define)}

a) Analisis front-end yaitu analisis yang dilakukan dengan mewawancara pendidik dan pezerta didik untuk menetapkan masalah dasar pada pembelajaran.

b) Analisis konsep yaitu analisis ini dilakukan dengan metode wawancara untuk mengidentifikasikan konsep pokok yang akan diajarkan, menyusunnya dalam bentuk struktur kemudian merinci konsep-konsep individu kehal yang kritis. Setelah analisis ini dilakukan maka dapat mengidentifikasikan bagian penting yang akan dipelajari, menyusun secara sistematis, dan submateri yang relevan akan masuk pada bahan ajar berdasarkan Prasyarat, Petunjuk Penggunaan, Kompetensi Isi (KI), Kompetensi Dasar (KD) dari bahan ajar berupa modul dengan pendekatan Discovery Learning.

c) Analisis tugas yaitu menggunakan metode wawancara untuk mengidentifikasikan keterampilan utama yang akan dikaji kemudian menganalis kedalam himpunan keterampilan tambahan adalah analisis tugas. Analisis ini 
memastikan secara menyeluruh mengenai tugas dalam materi. Berdasarkan hasil analisis maka diperoleh gambaran mengenai tugas-tugas yang diperlukan pada pembelajaran sesuai kompetensi dasar.

d) Perumusan tujuan pembelajaran yaitu merangkum hasil dari analisis konsep dan analisis tugas untuk menentukan prilaku objek penelitian merupakan perumusan tujuan pembelajaran. Menyusun tes kemudian merancang bahan ajar yang diintegrasikan kedalam materi yang terdapat didalam modul adalah dasar dari kumpulan objek penelitian. Analisis ini memperoleh tujuan-tujuan pembelajaran yang akan dicapai oleh bahan ajar berupa modul dengan pendekatan Discovery Learning yang dikembangkan.

\subsubsection{Tahap II: Perencanaan (Design)}

Merancang bahan ajar modul untuk memperoleh draf awal merupakan tujuan dari tahap ini.

a) Penyusunan tes acuan patokan adalah langkah yang menyatukan antara tahap pendefinisian dan tahap perancangan merupakan penyusunan tes acuan patokan.

b) Pemilihan bahan ajar adalah bahan ajar yang ditunjuk yaitu bahan ajar berupa modul dengan pendekatan Discovery Learning yang bertujuan untuk memudahkan dalam pembelajaran.

c) Pemilihan format adalah pemilihan format dimaksudkan untuk mendesain isi pembelajaran dalam mengembangkan perangkat pembelajaran.

d) Rancangan awal adalah rancangan dari semua perangkat pembelajaran seperti bahan ajar yang perlu dikerjakan sebelum uji coba dilaksanakan adalah rancangan awal.

\subsubsection{Tahap III: Pengembangan (Develop)}

Membentuk bahan ajar berupa modul dengan pendekatan discovery learning merupakan tujuan pada tahap ini. Selain itu, peneliti melakukan validasi modul kepada 3 orang ahli, yaitu: ahli materi, ahli desain, dan ahli bahasa serta melakukan uji coba respon peserta didik dan guru.

a) Uji kelayakan / validasi ahli. Untuk mengetahui valid tidaknya suatu bahan ajar dengan kualifikasi tertentu maka dilakukan uji/validasi. Dalam pengembangan ini di validasi oleh tiga ahli, yaitu:

1) Uji ahli materi. Uji ahli materi menggunakan satu orang ahli materi yakni satu guru MTs Darul A'mal Metro yang mengajar pada bidang mata pelajaran matematika pemilihan ahli materi ini didasarkan pada kompetensi para ahli materi yang mumpuni pada materi himpunan.

2) Uji ahli desain. Uji ahli desain menggunakan satu orang ahli desain yaitu dosen IAIM NU Metro Lampung yang ahli dalam bidang teknologi tersebut. Pemilihan ahli desain tersebut karena kemampuan ahli desain dalam desain bahan ajar.

3) Uji ahli bahasa. Uji ahli bahasa menggunakan satu orang ahli bahasa yakni satu guru MTs Darul A'mal Metro yang mengajar pada bidang mata pelajaran bahasa Indonesia. 
b) Revisi produk. Setelah desain produk di validasi oleh ahli materi, ahli desain dan ahli bahasa maka dapat diketahui kekurangan dari Bahan Ajar tersebut. Kekurangan tersebut kemudian diperbaiki untuk menghasilkan produk yang lebih baik lagi.

c) Uji coba produk. Setelah produk selesai dibuat dan direvisi, selanjutkan diuji cobakan dalam kegiatan pembelajaran. Tujuan dari uji coba produk untuk mendapatkan informasi apakah bahan ajar yang dikembangkan dalam menyampaikan materi himpunan lebih efektif dan bermanfaat atau tidak dibandingkan dengan bahan pembelajaran yang digunakan oleh pendidik sebelumnya. Pada Uji coba produk dapat dilakukan dengan cara uji coba lapangan.

d) Revisi produk. Dari uji coba produk, apabila respon peserta didik dan pendidik mengatakan produk ini layak dan menarik, maka dapat dikatakan produk ini telah selesai dikembangkan sehingga menyelesaikan produk akhir. Dari segi kemenarikan perangkat pembelajaran siswa MTs menunjukan yaitu bahan ajar berupa modul dengan pendekatan discovery learning ini ternyata lebih menarik bagi proses pembelajaran dari pada sebelumnya sehingga dikatakan bahwa bahan pembelajaran telah selesai dikembangkan dan menghasilkan produk akhir. Apabila produk belum sempurna maka hasil uji coba dibuat bahan perbaikan dan penyempurnaan bahan pembelajaran dan kemudian dapat menghasilkan produk akhir yang siap digunakan.

\subsection{Teknik Pengumpulan Data}

Teknik pengumpulan data pada penelitian ini menggunakan dua jenis, yaitu:

\subsubsection{Wawancara}

Wawancara merupakan metode untuk mendapatkan data dengan melakukan tanya jawab antara penanya dan responden [12]. Wawancara digunakan sebagai strategi pengumpulan informasi guna menemukan masalah yang harus dianalisis dan mengetahui hal-hal yang dialami responden secara lebih mendalam. Wawancara dilakukan dengan narasumber guru pendidikan matematika kelas VII di MTs Daru A'mal Metro dan juga peserta sidik kelas VII. Wawancara ini dilakukan untuk mendapatkan informasi yang akan digunakan sebagai masukan untuk untuk mengembangkan Bahan ajar berupa modul dengan pendekatan Discovery Learning.

\subsubsection{Angket (kuisioner)}

Kuisioner adalah daftar pertanyaan yang disampaikan oleh peneliti untuk diisi dan dikembalikan atau dapat juga dijawab di bawah pengawasan peneliti [13] Angkat (kuisioner) digunakan untuk mengevaluasi dan menguji (uji coba) bahan ajar dalam bentuk modul dengan pendekatan Discovry Learning. Hal ini dilakukan oleh validator ahli materi, validator ahli desain, dan validator ahli bahasa. Sedangkan uji coba bahan ajar berupa modul dengan pendekatan Discovery Learning dengan memberikan angket peserta didik uji coba lapangan dan pendidik. 


\subsection{Teknik Analisis Data}

Analisis data pada penelitian ini mengggunakan teknik analisis derkriptif kualitatif dan kuantitatif. Kualitatif yaitu data yang didapat dari validator pada tahap validasi. Selain itu, kuamtitatif yaitu data yang menjelaskan hasil pengembangan produk yang berupa desain bahan ajar. Hasil analisis data kemudian digunakan sebagai acuan unuk melakukan revisi produk yang akan dikembangkan.

Rumusan untuk menentukan jarak interval dari sangat kurang (SK) sampai sangat baik (SB) yaitu:

$$
\text { Skor rata-rata }(\bar{X})=\frac{\text { Jumlah Skor maksimal }\left(\sum X\right)}{\text { Jumlah Skor yang didapat }(n)} \times 100
$$

Data hasil dari angket validasi para ahli dianalisis dengan acuan yang diadaptasi menggunakan skala likert, sebagai berikut:

Tabel 1: Kriteria interpretasi skor

\begin{tabular}{cl}
\hline Kriteria (\%) & \multicolumn{1}{c}{ Klasifikasi } \\
\hline $80 \%<\bar{X} \leq 100 \%$ & Sangat layak \\
$60 \%<\bar{X} \leq 80 \%$ & Layak \\
$40 \%<\bar{X} \leq 60 \%$ & Cukup layak \\
$20 \%<\bar{X} \leq 40 \%$ & Kurang layak \\
$0 \%<\bar{X} \leq 20 \%$ & Sangat kurang layak \\
\hline
\end{tabular}

Kriteria sikap respon terhadap hasil produk dari pengembangann dan penelitiian, sebagai berikut:

Tabel 2: Skala likert

\begin{tabular}{lc}
\hline \multicolumn{1}{c}{ Penilaian } & Skor \\
\hline Sangat menarik & 5 \\
Menarik & 4 \\
Cukup menarik & 3 \\
Kurang menarik & 2 \\
Sangat kurang menarik & 1 \\
\hline
\end{tabular}

Berdasarkan tabel skala likert, maka produk pengembangan akan berakhir saat skor penilaian terhadap desain Bahan Ajar telah memenuhi syarat atau dengan kata lain telah mencapai klasifikasi layak.

\section{Hasil dan Pembahasan}

\subsection{Pendefenisian (Define)}

\subsubsection{Analisis Front-end}

Tahap ini dilakukan sebelum melakukan pengembangan terhadap bahan ajar Modul dengan cara menganalisis kebutuhan yang diperlukan dalam proses pembelajaran di kelas VII MTs Darul A'mal. Pada tahap ini peneliti melaksanakan wawancara dengan guru matematika dan membagi angket disalah satu kelas VII. Wawancara dilaksanakan pada tanggal 02 Oktober 2019 dengan narasumber Ibu Effi Ninda Wahyuningsih, S. Pd. Berdasarkan hasil wawancara dan observasi yang dilakukan diperoleh informasi bahwa 
dalam proses belajar mengajar guru hanya menggunakan LKS yang telah disesuaikan kurikulum 2013. Belum ada yang menggunakan bahan ajar berupa Modul terlebih pada materi Himpunan. Masalah-masalah yang ada tersebut memberikan ide kepada peneliti untuk mengembangkan bahan ajar Modul dengan pendekatan Discovery Learning. Berdasarkan apa yang ditemukan di lapangan, perlu dikembangkan bahan ajar berupa modul dengan pendekatan Discovery Learning pada materi Himpunan di kelas VII MTs Darul A'mal Metro.

\subsubsection{Analisis konsep}

Pada tahap ini peneliti melakukan wawancara dengan guru matematika kelas VII di MTs Darul A'mal Metro untuk mendapatkan informasi lebih jauh mengenai bahan ajar modul terutama bagaimana penyusunan modul, teknik penulisan dalam modul, bagaimana langkah-langkah Discovery Learning dan materi pokok bahasan Himpunan yang telah disesuaikan dengan KI ataupun KD.

\subsubsection{Analisis Tugas}

Melakukan analisis kebutuhan dengan penyebaran angket dan wawancara terhadap pendidik yang mengumpu mata pelajaran matematika di MTs Darul A'mal Metro. Berdasarkan penyebaran angket dan wawancara terhadap pendidik di sekolah didapatkan bahwa proses pembelajaran yang diterapkan disekolah sudah menggunakan bahan ajar pembelajaran. Akan tetapi penggunaan bahan ajar hanya sebatas Lembar Kerja Siswa (LKS).

\subsubsection{Perumusan Tujuan Pembelajaran}

Peneliti melakukan wawancara kepada pendidik yang mengampu mata pelajaran Matematika. Berdasarkan hasil wawancara tersebut materi himpunan yang diterapkan dalam sebuah bahan ajar modul dengan pendekatan Discovery Learning belum ada. Sehingga perlu mengembangkan bahan ajar modul dengan pendekatan Discovery Learning pada materi himpunan.

\subsection{Perancanaan (Design)}

\subsubsection{Penyusunan Tes Acuan Patokan}

Langkah yang menyatukan antara tahap pendefinisian dan tahap perancangan merupakan penyusunan tes acuan patokan. Tahap ini merupakan tahap dimana peneliti mulai merancang bahan ajar modul dengan pendekatan Discovery Learning. Pengembangan bahan ajar ini diawali dengan menyusun isi program seperti memulai pengetikan materi, membuat contoh soal, membuat latihan-latihan soal, dan evaluasi, serta membuat desain modul. Selanjutnya menentukan urutan penyajian yang sesuai dengan Discovery Learning.

\subsubsection{Pemilihan Bahan Ajar}

Bahan ajar yang dipilih yakni bahan ajar berupa Modul, yang dikembangkan menjadi bahan ajar Modul dengan pendekatan Discovery Learning. Modul dipilih untuk disajikan sebagai bahan ajar pembelajaran visual untuk memberikan kemudahan bagi siswa dan kemenarikan dalam proses pembelajaran. Kemudian disesuaikan dengan 
analisis tugas, analisis konsep, dan selanjutnya divalidasi serta diuji cobakan pada tahap pengembangan.

\subsubsection{Pemilihan Format}

Pada tahap ini peneliti memilih format yang akan digunakan dalam mendesain bahan ajar. Bahan ajar ini menggunakan ukuran kertas A4; skala spasi 1,5; jenis huruf Times New Roman, Hobo Std, Eras Bold ITC, Bernard MT Condensed, Bodoni MT Black.

\subsubsection{Rancangan Awal}

Menyesuaikan kompetensi inti, kompetensi dasar, dan silabus berdasarkan kurikulum 2013 adalah langkah-langkah dalam membuat rancangan awal desain produk ini. Cover depan, kata pengantar, daftar isi, peta konsep, petunjuk penggunaan Modul, skema materi himpunan yang terdapat KI dan KD, halaman awal subbab, contoh soal, latihan soal, rangkuman, soal-soal ulangan akhir dan daftar pustaka merupakan rancangan awal pada pengembangan Modul.

\subsection{Pengembangan (Develop)}

\subsubsection{Uji Kelayakan / Validasi Ahli}

Modul yang telah didesain, selanjutnya divalidasi terhadap validator ahli materi, validator ahli desain, dan validator ahli bahasa. Ahli materi menilai beberapa aspek yaitu: kesesuaian materi dengan KD, keakuratan materi, kemuktahiran materi, mendorong keingintahuan, teknik penyajian, pendukung penyajian, penyajian pembelajaran, dan koherensi dan keruntutan alur. Ahli desain menilai beberapa aspek yaitu: Ukuran bahan ajar, Desain Sampul Bahan Ajar (cover), dan Desain Isi Modul. Ahli bahasa menilai beberapa aspek yaitu: aspek Lugas; Komunikatif; Dialogis dan Interaktif; Kesesuaina dengan Tingkat Perkembangan Peserta Didik; Keruntutan dan Keterpaduan Alur Pikir; dan Penggunaan Istilah, Simbol, atau Ikon. Penentuan subyek ahli mempuyai kriteria yaitu berpengalaman di bidangnya. Deskripsi hasil validasi oleh ahli materi, ahli desain dan ahli bahasa tahap I disajikan pada Tabel 3.

Tabel 3: hasil validasi dari masing-masing ahli pada tahap I

\begin{tabular}{llll}
\hline No. & Validator & Persentase & Kriteria \\
\hline 1. & Ahli Materi & $68 \%$ & Layak \\
2. & Ahli Desain & $67 \%$ & Layak \\
3. & Ahli Bahasa & $68 \%$ & Layak \\
\hline \multicolumn{2}{l}{ Rata-Rata Validasi Ahli } & $68 \%$ & Layak \\
\hline
\end{tabular}

\subsubsection{Revisi Produk}

Setelah desain produk divalidasi oleh ahli materi, ahli desain dan ahli bahasa, peneliti melakukan revisi terhadap desain produk yang dikembangkan berdasarkan masukanmasukan ahli tersebut. Deskripsi hasil validasi oleh ahli materi, ahli desain dan ahli bahasa tahap II disajikan pada Tabel 4. 
Tabel 4: hasil validasi dari masing-masing ahli pada tahap II

\begin{tabular}{llll}
\hline No. & Validator & Persentase & Kriteria \\
\hline 1. & Ahli Materi & $83 \%$ & Sangat layak \\
2. & Ahli Desain & $88 \%$ & Sangat layak \\
3. & Ahli Bahasa & $89 \%$ & Sangat layak \\
\hline \multicolumn{2}{l}{ Rata-Rata Validasi Ahli } & $88 \%$ & Sangat layak \\
\hline
\end{tabular}

Gambaran persentasi hasil validasi ahli sebelum dan setelah direvisi ditampilkan pada Gambar 1, Gambar 2, dan Gambar 3.

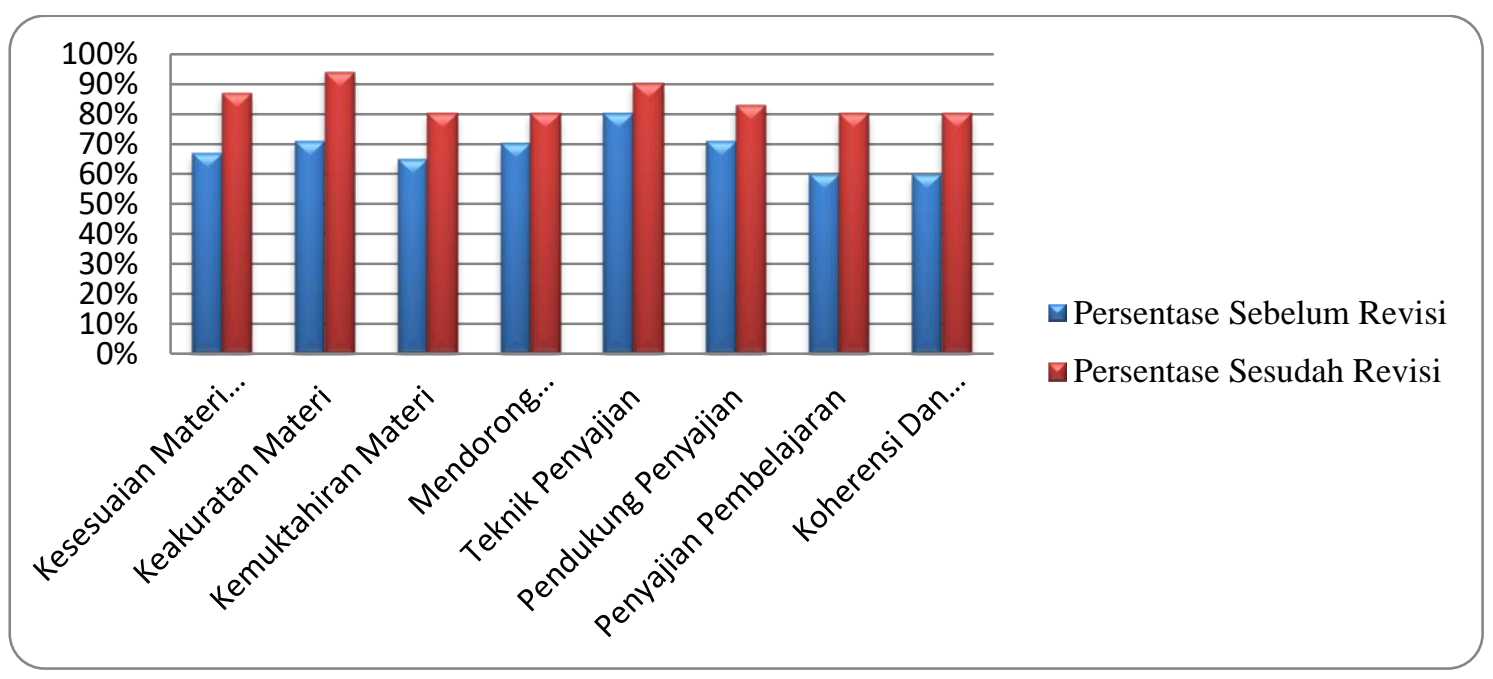

Gambar 1: perbandingan persentase ahli materi

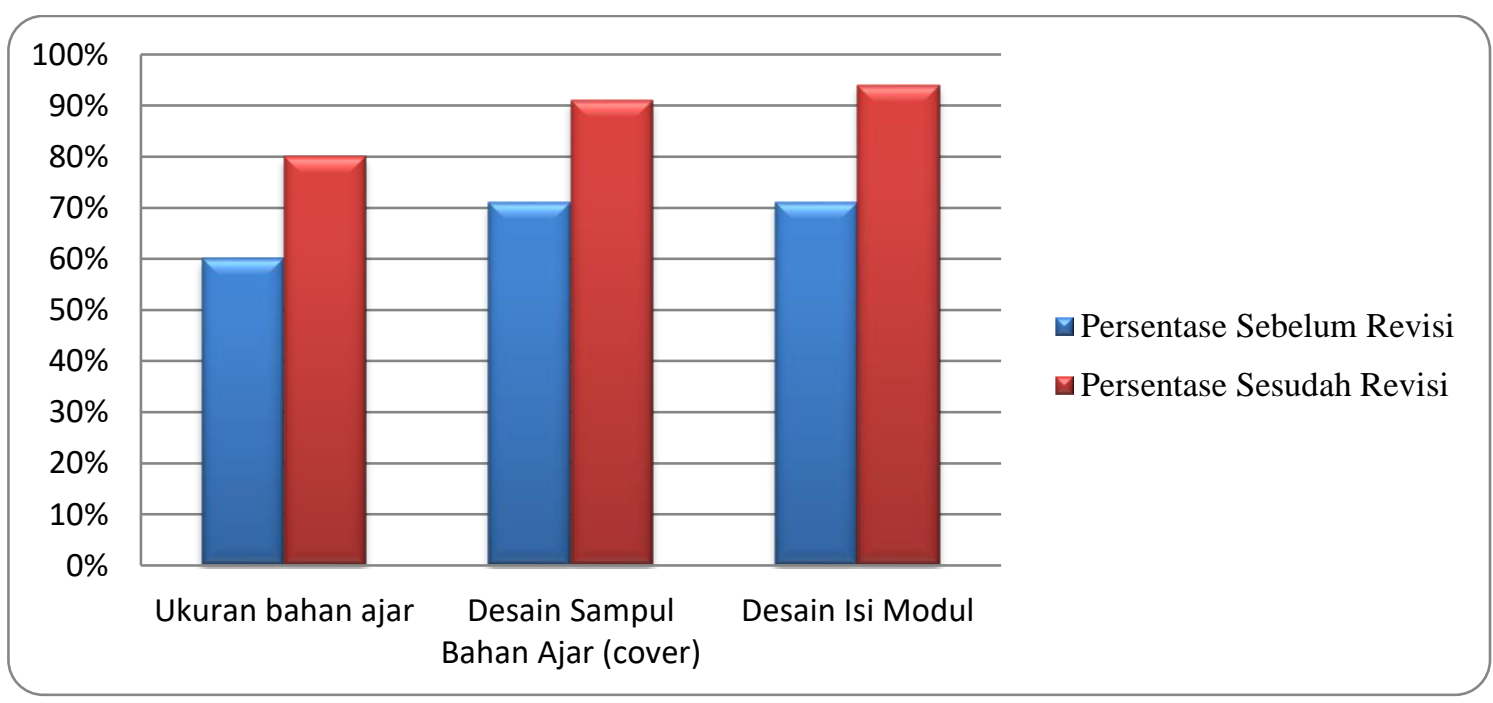

Gambar 2: perbandingan persentase ahli desain 


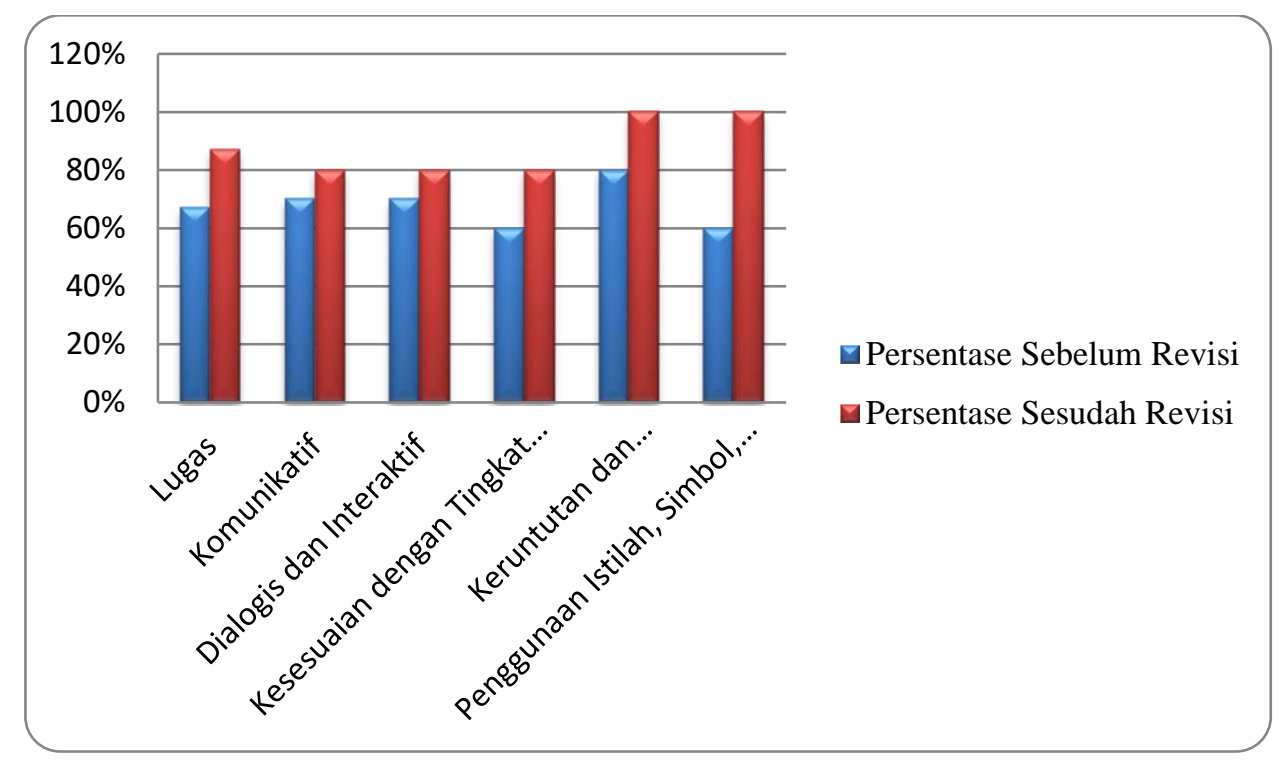

Gambar 3: perbandingan persentase ahli Bahasa

Gambar 1, Gambar 2, dan Gambar 3 menunjukkan bahwa indikator secara kesuluran baik dari aspek materi, desain, mapun tata Bahasa telah mengalami perbaikan yang cukup signifikan sehingga produk yang dihasilkan dapat digunakan pada proses pembelajaran.

\subsection{Uji Coba Produk}

Uji coba lapangan dilakukan untuk meyakinkan data dan mengetahui kemenarikan produk secara luas. Responden pada uji coba lapangan ini terdiri dari peserta didik dan pendidik. Peserta didik yang berjumlah 27 di kelas VII MTs Darul A'mal dengan cara memberi angket untuk mengetahui respons peserta didik terhadap kemenarikan Modul. Hasil uji coba lapangan di MTs Darul A'mal Metro dicapai nilai rata-rata 74\% dengan kriteria yaitu "menarik". Hasil uji coba pendidik memperoleh persentase $74 \%$ dengan kriteria interpretasi yang dicapai yaitu "menarik", hal ini berarti bahan ajar yang dikembangkan oleh peneliti mempunyai kriteria menarik untuk digunakan sebagai alat bantu dalam kegiatan belajar mengajar pada materi Himpunan untuk kelas VII $\mathrm{SMP} / \mathrm{MTs}$.

\subsection{Revisi Produk}

Dari uji coba produk, respon peserta didik dan pendidik mengatakan produk ini layak dan menarik, tetapi masih contoh-contoh soal kurang banyak dan desain cover dan desain halaman isi kurang menarik. Selain itu, validasi juga masih dilakukan oleh satu orang ahli.

Berdasarkan validasi dan revisi yang telah dilakukan serta uji coba yang telah dilakukan, maka tujuan pengembangan untuk menghasilkan produk berupa bahan ajar Modul dengan pendekatan Discovery Learning pada materi himpunan sudah sesuai dengan tujuan pengembangan. Bahan ajar Modul dengan pendekatan Discovery Learning pada materi himpunan yang akan dikembangkan diharapkan dapat membantu peserta didik dalam memahami konsep materi, efektif sebagai sumber belajar peserta didik yang lebih baik lagi, membuat peserta didik lebih tertarik untuk belajar matematika. 


\section{Kesimpulan}

Bahan ajar modul dengan pendekatan Discovery Learning pada materi himpunan dikembangkan dengan menggunakan tiga tahapan yaitu define, design dan develop. Bahan ajar telah divalidasi dengan nilai rata-rata sebesar 79\% dengan kriteria "layak". Dengan demikian, bahan ajar modul dengan pendekatan Discovery Learning pada materi himpunan layak digunakan sebagai bahan ajar. Selanjutnya, bahan ajar yang dikembangkan mendapatkan respon positif dari peserta didik dengan persentase $74 \%$ dalam kategori "menarik".

\section{Referensi}

[1] E. N. Wahyuningsih, “Wawancara," Oktober-2019.

[2] Sungkono, "Pengembangan dan Pemanfaatan Bahan Ajar Modul Dalam Proses Pembelajaran," Usej, vol. Vol 2, 2013.

[3] S. Khadijah, S. Ismail, and R. Resmawan, "Pengembangan Bahan Ajar Berbasis Penalaran pada Materi Sudut Pusat dan Sudut Keliling Lingkaran," Al-Khwarizmi J. Pendidik. Mat. dan Ilmu Pengetah. Alam, vol. 8, no. 1, pp. 1-12, Apr. 2020, doi: 10.24256/jpmipa.v8i1.838.

[4] S. D. Tamu, E. Hulukati, and I. Djakaria, "Pengembangan Modul dan Video Pembelajaran Matematika Persiapan Ujian Nasional pada Materi Dimensi Tiga," Jambura J. Math. Educ., vol. 1, no. 1, pp. 21-31, Mar. 2020, doi: 10.34312/jmathedu.v1i1.4558.

[5] S. Wahyuni, M. Yati, and A. Fadila, "Pengembangan Modul Matematika Berbasis REACT terhadap Kemampuan Komunikasi Matematis Peserta Didik," Jambura J. Math. Educ., vol. 1, no. 1, pp. 1-12, Feb. 2020, doi: 10.34312/jmathedu.v1i1.4542.

[6] Abdillah, "Pengembangan Modul Dengan Menggunakan Pendekatan Pembelajaran Discovery Learning Untuk Meningkatkan Hasil Belajar," J Pemikir Dan Peneliti Pendidik. Mat, vol. Vol 1 No 2, 2018.

[7] M. Nurdin, "Pengaruh Metode Discovery Learning untuk Meningkatkan Representasi Matematika dan Percaya Diri Siswa," J. Penelit. Univ. Garut, vol. Vol. 09 No. 01, 2016.

[8] Sugiono, Metode Penelitian Pendidikan. Bandung: Alfabeta, 2011.

[9] A. D. Kurniawan, "Pengembangan Buku Siswa untuk Meningkatkan Proses dan Hasil Belajar Kompetensi Dasar Cornflase Cookies Pada Siswa Tunagrahita SMALB Negeri Gedangan, Sidoarjo," E-J Boga, vol. Vol. 2 No.1, 2013.

[10] Novianti, D. A., "Pengembangan Modul Akuntansi Aset Tetap Berbasis Pendekatan Saintifik Sebagai Pendukung Implementasi K-13 di SMKN 2 Buduran," J Pendidik., vol. Vol. 3 No. 1, 2015.

[11] S. Nasution, Metode Research (Penelitian Ilmiah), Ed. 1. Jakarta: Bumi Aksara, 2016.

[12] N. Muhamad, "Pengaruh Metode Discovery Learning untuk Meningkatkan Representasi Matematis dan Percaya Diri Siswa," J. Penelit. Univ. Garut, vol. 09, no. 01, hlm. 12, 2016.

[13] R. Abdul Sani, Pembelajaran Saintifik untuk Implementasi Kurikulum 2013, Keempat. Jakarta: Bumi Aksara, 2017. 